\title{
PENINGKATAN KEMAMPUAN MENULIS KARANGAN NARASI DENGAN METODE PETA PIKIRAN DALAM PEMBELAJARAN BAHASA INDONESIA
}

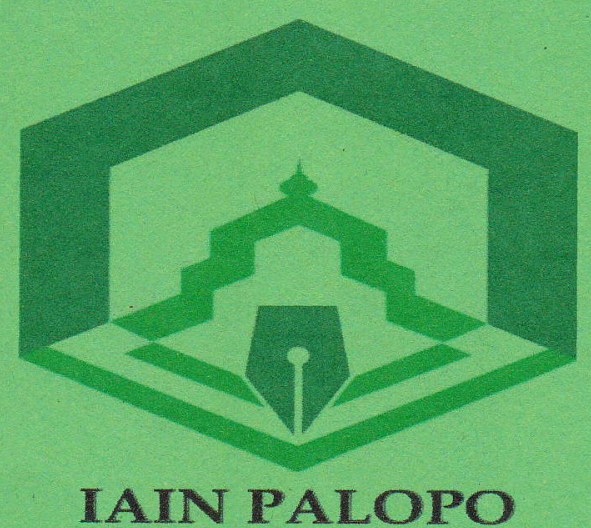

HASIL PENELITIAN

\author{
Ketua Tim : Mirnawati, S.Pd, M.Pd \\ Sekertaris $\quad$ : Lilis Suryani, S.Pd, M.Pd \\ Anggota Tim : 1. Jusriana Wati Dewi/ Semester VIII \\ 2.Jumrah / Semester VII \\ 3. Wais Alqorni/ Semester VII
}

INSTITUT AGAMA ISLAM NEGERI (IAIN) PALOPO 


\section{KEMENTERIAN AGAMA REPUBLIK INDONESIA INSTITUT AGAMA ISLAM NEGERI (IAIN) PALOPO FAKULTAS TARBIYAH DAN ILMU KEGURUAN \\ J. Agatis Balandai Telp. 0471-22076 Fax 0417-325195 Kota palopo

\section{SURAT TUGAS \\ Nomor: $1121 /$ In.19/FTIK/PP.00.9/09/2017}

Dalam rangka Penelitian pengabdian kepada Masyarakat oleh Dosen PGMI, dengan judul "Peningkatan Kemampuan Menulis Karangan Narasi dengan Metode Peta Pikiran dalam Pembelajaran Bahasa Indonesia" maka Dekan FTIK memberi surat tugas kepada:

\begin{tabular}{|c|l|l|}
\hline NO & \multicolumn{1}{|c|}{ NAMA } & \multicolumn{1}{|c|}{ JABATAN } \\
\hline 1 & Mirnawati, S.Pd., M.Pd & Ketua Tim \\
\hline 2 & Lilis Suryani, S.Pd., M.Pd & Sekertaris \\
\hline 3 & Jusrianawati Dewi & Pembantu Lapangan \\
\hline 4 & Jumrah & Pembantu Lapangan \\
\hline 5 & Wais Alqorni & Pengelolah Data \\
\hline
\end{tabular}

Untuk melaksanakan penelitian di Palopo pada hari rabu, 21 September 2017

Demikian, untuk dilaksanakan. 


\title{
PENINGKATAN KEMAMPUAN MENULIS KARANGAN NARASI DENGAN METODE PETA PIKIRAN DALAM PEMBELAJARAN BAHASA INDONESIA
}

\author{
Dian Dinarti, Siti Halidjah, Endang Uliyanti \\ PGSD, FKIP Institute Agama Islam Negeri \\ Palopo email: D3yan_08@yahoo.co.id
}

\begin{abstract}
Abstrak: Peningkatan Kemampuan Menulis Karangan Narasi dengan Metode Peta Pikiran (Mind Mapping) dalam Pembelajaran Bahasa Indonesia pada Siswa Kelas V SDN 34 Palopo Kota. Penelitian ini bertujuan untuk meningkatkan kemampuan siswa menulis karangan narasi dengan metode peta pikiran Penelitian ini menggunakan pendekatan kualitatif, metode deskriptif, bentuk penelitian tindakan kelas (PTK), dan bersifat kolaboratif. Subyek penelitian adalah guru mata pelajaran bahasa Indonesia dan siswa kelas VB SDN 34 Palopo Kota.Teknik pengumpul data adalah observasi langsung dan pengukuran. Alat pengumpul data adalah lembar observasi (IPKG 2) dan unjuk kerja siswa. Dari data yang diperoleh hasil penilaian pelaksanaan pembelajaran terhadap guru dari base line sampai siklus II dengan skor rata-rata yaitu $(2,65),(3,32)$, $(3,74)$. Hasil penilaian menulis karangan narasi dari base line sampai siklus II dengan skor rata- rata yaitu $(61,8),(73,15),(81,11)$. Kesimpulan, proses pelaksanaan pembelajaran dan kemampuan menulis karangan narasi dengan metode peta pikiran pada siswa kelas $\mathrm{V}$ mengalami peningkatan.
\end{abstract}

Kata Kunci: Peningkatan, Karangan Narasi, Metode Peta Pikiran

\begin{abstract}
Improving writing ability on narrative essay through mind mapping method in bahasa Indonesia subject. The purpose of this research is to improve student's writing ability through mind mapping method. The subjects of this research are the bahasa Indonesia teacher and the fifth grade students of SDN 34

Palopo Kota. The techniques of data collecting are direct observation and measurement. The tool of data collecting is direct observation and the result of student's writing. The tool is also collected from the result of implementation of learning assesment toward the teacher, it started from base line until second cycle with the average score is $(2,65),(3,32),(3,74)$. The average score of the assesment of student's essay writing on narrative from base line until second cycle is $(61,8),(73,15),(81,11)$. The process of learning implementation and the ability to write a narrative essay of fifth grade students have increased.
\end{abstract}

Key Word: Improving, Narrative Essay, Mind Mapping Method 
Bahasa adalah sarana yang digunakan untuk berkomunikasi dengan sesama manusia dalam kehidupan sehari-hari. Dengan adanya bahasa, tujuan komunikasi akan tercapai. Maksud komunikasi disini yaitu suatu proses penyampaian maksud pembicara kepada orang lain dengan menggunakan saluran tertentu. Maksud komunikasi dapat berupa pengungkapan pikiran, gagasan, ide, pendapat, persetujuan, keinginan, penyampaian informasi tentang suatu peristiwa, dan lain- lain.

Bahasa memiliki peran sentral dalam perkembangan intelektual, sosial dan emosional para siswa dan merupakan penunjang keberhasilan dalam mempelajari semua mata pelajaran. Hal ini sesuai dengan Kurikulum Tingkat Satuan Pendidikan 2006 yang menyatakan bahwa pembelajaran bahasa diharapkan membantu peserta didik mengenal dirinya, budayanya, dan budaya orang lain, mengemukakan gagasan dan perasaan , berpartisipasi dalam masyarakat yang menggunakan bahasa tersebut, dan menemukan serta menggunakan kemampuan analitis dan imaginatif yang ada dalam dirinya. (KTSP, 2006:317).

Berdasarkan tujuan dari pembelajaran bahasa Indonesia terdapat empat aspek berbahasa yang harus dikuasai oleh peserta didik yaitu keterampilan mendengarkan, berbicara, membaca dan menulis. Keterampilan menulis sebagai salah satu dari empat keterampilan berbahasa yang mempunyai peranan penting dalam kehidupan manusia.

Salah satu keterampilan menulis yang dapat menentukan keberhasilan berbahasa tulis siswa tercantum dalam Kurikulum Tingkat Satuan Pendidikan 2006 kelas V Sekolah Dasar dengan standar kompetensi, yaitu: mengungkapkan pikiran, perasaan, dan informasi secara tertulis dalam karangan, surat undangan, dan dialog tertulis (KTSP, 2006:325). Maka sesuai kompetensi dasarnya adalah menulis karangan berdasarkan pengalaman dengan memperhatikan pilihan kata dan penggunaan ejaan. Kemampuan menulis dapat dinilai jika siswa ditugaskan untuk mengarang. Ada empat jenis karangan yang harus dipelajari dalam pelajaran menulis yaitu narasi, deskripsi, eksposisi dan argumentasi. Salah satu kemampuan menulis karangan yang sesuai dengan siswa sekolah dasar adalah menulis karangan narasi. Karangan narasi merupakan jenis karangan yang bercerita, baik berdasarkan pengalaman, pengamatan, maupun khayalan. Oleh karena itu siswa lebih mudah untuk menuangkan ide atau gagasannya ke dalam bentuk tulisan. Khundaru Saddono dan St. Y. Slamet(2012:101) menyimpulkan bahwa, narasi (penceritaan atau pengisahan) adalah ragam wacana yang menceritakan proses kejadian suatu peristiwa. Sasarannya adalah memberikan gambaran yang sejelas-jelasnya kepada pembaca mengenai fase, urutan, langkah, atau rangkaian terjadinya sesuatu hal.

Berdasarkan data hasil observasi sebelum dilaksanakan tindakan yang dilakukan pada tanggal 17 Juli 2012 di kelas VB Sekolah Dasar Negeri 34

Palopo Kota yang berjumlah 37 orang siswa ternyata hanya 10 orang siswa yang dapat menulis karangan narasi dengan baik sedangkan 27 orang atau sekitar $27,02 \%$ siswa masih kesulitan dalam menulis karangan narasi dengan skor rata- rata 61,8 yang memiliki kriteria ketuntasan minimal (KKM) 70. Kemudian hasil dari tes menulis karangan tersebut menunjukkan bahwa penguasaan kosakata 
untuk menghasilkan gagasan, mencatat apa yang dipelajari, atau merencanakan tugas baru. Suyatno (2009:94) menyimpulkan bahwa cara kerja peta pikiran adalah menuliskan tema utama sebagai titik sentral/tengah dan memikirkan cabang- cabang atau tema-tema turunan yang keluar dari titik tengah tersebut dan mencari hubungan antara tema turunan. Itu berarti setiap kali kita mempelajari sesuatu hal maka fokus kita diarahkan pada tema utamanya, poin-poin penting dari tema yang utama yang sedang kita pelajari, pengembangan dari setiap poin penting tersebut dan mencari hubungan antara setiap poin. Dari beberapa pendapat tersebut dapat disimpulkan bahwa peta pikiran adalah suatu cara memetakan sebuah informasi yang digambarkan ke dalam bentuk cabangcabang pikiran dengan berbagai imajinasi kreatif. Dengan peta pikiran akan membantu otak berpikir secara teratur.

Dalam pembelajaran bahasa Indonesia, siswa dapat menggunakan peta pikiran (mind mapping) sebagai gagasan dalam kegiatan menulis. Di dalam kegiatan menulis, peta pikiran membantu siswa menyusun informasi dan melancarkan aliran pikiran. Peta pikiran dapat membantu siswa dalam mengatasi hambatan menulis. Melalui peta pikiran (mind mapping) siswa lebih mudah dalam mengorganisasikan pikirannya untuk dituangkan dalam bentuk narasi.

Untuk mengajak anak membuat peta pikiran, diperlukan beberapa hal, yaitu kertas kosong tak bergaris, pena atau spidol berwarna, otak dan imajinasi. Tony Buzan (2010:20) mengungkapkan bahwa ada beberapa cara untuk membuat peta pikiran (mind mapping). Beliau memberikan contoh menggambar peta pikiran (mind mapping) dengan tema liburanku. Langkah-langkah tersebut sebagai berikut (1) ambillah selembar kertas putih polos. (jangan menggunakan kertas bergaris-ini akan menghentikan aliran idemu), (2) ambillah beberapa spidol berwarna cerah, (3) gambar sebuah gambar di tengah halaman yang berhubungan dengan apa yang telah kamu lakukan atau kemana kamu pergi berlibur, lalu di atas, di bawah, atau di dalamnya, tulis "Liburanku" dengan huruf-huruf yang besar, (4) pilih sebuah warna dan gambarlah sebuah cabang utama yang memancar dari gambar sentral, (5) sekarang biarkan otakmu berpikir tentang gagasan-gagasan untuk mengembangkan cabangcabang utama, (6) Dengan semakin banyaknya gagasan yang muncul, tambahkan lebih banyak cabang ke subtopik.

Suyatno (2009:94) mengemukakan bahwa ada tujuh langkah untuk membuat peta pikiran (mind mapping). Tujuh langkah tersebut adalah sebagai berikut (1) mulailah dari bagian tengah kertas kosong yang sisi panjangnya diletakkan mendatar, (2) gunakan gambar atau foto untuk ide sentral, karena gambar melambangkan topik utama, (3) gunakan warna, karena bagi otak warna sama menariknya dengan gambar sehingga peta pikiran lebih hidup. (4) hubungkan cabang-cabang utama ke gambar pusat dan hubungkan cabang-cabang tingkat dua dan tiga ke tingkat satu dan dua, dan seterusnya. (5) buatlah garis hubung yang melengkung, (6) gunakan satu kata kunci untuk setiap cabang atau garis, (7) gunakan gambar, karena setiap gambar bermakna seribu kata.

Berdasarkan pendapat Tony Buzan (2010:20) dan Suyatno (2009:94) dapat disimpulkan bahwa langkah-langkah pembelajaran menulis karangan narasi dengan metode peta pikiran sebagai berikut: (1) siswa bersama guru memilih tema karangan kemudian menuliskannya di atas selembar kertas kosong, (2) siswa 
mengamati media gambar atau foto yang disediakan guru, (3) siswa menuliskan kata kunci dari ide-ide yang dipilih pada cabang-cabang yang melingkupi pusat ide karangan disertai dengan simbol-simbol atau gambar berwarna, (4) siswa ditugaskan untuk saling bertukar pikiran tentang peta pikiran yang mereka buat dengan teman sebangkunya, (5) setelah siswa membuat perencanaan dalam bentuk peta pikiran kemudian siswa ditugaskan untuk menulis karangan narasi, (6) setelah karangan yang dibuat siswa selesai, maka siswa ditugaskan untuk menandai hal-hal yang perlu diperbaiki dalam karangannya,(7) siswa memperbaiki karangannya, (8) siswa menyerahkan karangan kepada guru.

\section{METODE}

Penelitian ini menggunakan pendekatan kualitatif, metode deskriptif, bentuk penelitian tindakan kelas, dan bersifat kolaboratif. Penelitian dilaksanakan di kelas VB Sekolah Dasar Negeri 34 Palopo Kota.Pelaksanaan penelitian ini dilaksanakan selama 6 bulan yang dilakukan pada semester gasal pada bulan Juli sampai Desember 2012. Subjek dalam penelitian ini adalah siswa kelas VB Sekolah Dasar Negeri 34 Palopo Kota dan guru yang mengajar di kelas VB tersebut dalam hal ini guru mata pelajaran bahasa Indonesia.

Menurut Kunandar (2011:127), indikator kinerja adalah suatu kriteria yang digunakan untuk melihat tingkat keberhasilan dari kegiatan PTK dalam meningkatkan atau memperbaiki mutu PBM di kelas. Indikator kinerja harus realistis dan dapat diukur. Adapun indikator kinerja dalam penelitian ini adalah (1) kesesuaian judul dengan isi karangan, (2) isi karangan, (3) organisasi isi, (4) ketepatan pilihan kata, (5) penggunaan ejaan dan tanda baca.

Menurut Wijaya Kusumah dan Dedi Dwitagama (2011:25), tahapan pelaksanaan Penelitian Tindakan Kelas adalah sebagai berikut (1) perencanaan (planning), (2) tindakan (acting), (3) pengamatan (observing), (4) refleksi (reflecting).

Teknik pengumpul data merupakan cara-cara yang dapat digunakan oleh peneliti untuk mendapatkan data. Teknik pengumpul data yang digunakan peneliti adalah (1) observasi langsung, (2) pengukuran. Teknik observasi langsung adalah cara mengumpulkan data yang dilakukan melalui pengamatan dan pencatatan gejala-gejala yang tampak pada obyek penelitian yang pelaksanaannya langsung pada tempat dimana suatu peristiwa, keadaan atau situasi sedang terjadi (Hadari Nawawi, 2007:100). Dalam penelitian ini, pengamatan dilakukan secara langsung pada siswa kelas V Sekolah Dasar Negeri 34 Palopo Kota dalam proses pembelajaran bahasa Indonesia dengan menggunakan metode peta pikiran (mind mapping). Teknik pengukuran adalah cara mengumpulkan data yang bersifat kuantitatif untuk mengetahui tingkat atau derajat aspek tertentu dibandingkan dengan norma tertentu pula sebagai satuan ukur yang relevan (Hadari Nawawi, 2007:101). Teknik pengukuran ini dimaksudkan untuk mengukur tingkat kemampuan menulis karangan narasi dilihat dari aspek-aspek yang diteliti yaitu: kesesuaian judul dengan isi karangan, isi karangan/gagasan, organisasi isi, pilihan kata, ejaan dan tanda baca dilanjutkan dengan pemberian skor. Data diambil dari hasil tes yang dilakukan siswa setelah proses pembelajaran. Lembar pengamatan sebagai alat pengumpul data teknik observasi langsung. Unjuk kerja digunakan 
sebagai alat pengumpul data pada teknik pengukuran, dalam hal ini unjuk kerja yang digunakan berupa karangan siswa yaitu karangan narasi. Penilaian unjuk kerja menggunakan skala penilaian (Rating scale) yang memungkinkan penilai memberi nilai tengah terhadap penguasaan kompetensi tertentu, karena pemberian nilai secara kontinum dimana pilihan kategori nilai lebih dari dua (Nabisi Lapono, 2008:176).

Analisis data dalam penelitian ini adalah menyeleksi dan memilah-milah data yang diperlukan. Kemudian dideskripsikan dan disajikan dalam bentuk tabel dan dibuatlah kesimpulan. Penyajian data melalui teknik observasi dan teknik pengukuran dalam penelitian ini, dianalisis dengan perhitungan rata-rata.

Untuk menjawab submasalah 1 dengan menggunakan lembar IPKG 2 yang mengadopsi dari panduan pelaksanaan program pengalaman lapangan FKIP UNTAN. IPKG 2 digunakan untuk melihat kemampuan guru kolaborator melaksanakan pembelajaran menulis karangan narasi dengan metode peta pikiran (mind mapping).

Untuk menjawab submasalah 2 yaitu menghitung rata-rata kemampuan siswa peraspek digunakan rumus sebagai berikut.

$$
X=\frac{x}{x} \quad \text { (Burhan Nurgyantoro, 2009:64) }
$$

Untuk menghitung persentasinya digunakan rumus sebagai berikut.

$$
P=1 \times \text { 回回\% } \quad \text { (Anas Sudijono, 2010:43) }
$$

Jika persentasinya dalam setiap siklus meningkat maka dapat disimpulkan bahwa metode peta pikiran (mind mapping) dapat meningkatkan kemampuan siswa dalam menulis karangan narasi.

\section{HASIL DAN PEMBAHASAN}

\section{Hasil Penelitian}

\section{Paparan data hasil Observasi Awal}

Berikut ini hasil observasi awal yang telah dilaksanakan peneliti pada tanggal 17 Juli 2012 terhadap guru bahasa Indonesia kelas VB di Sekolah Dasar Negeri 34 Palopo Kota sebelum menggunakan metode peta pikiran (mind mapping) dapat dilihat pada tabel di bawah ini.

Tabel 1

Penilaian Pelaksanaan Pembeljaraan terhadap Guru

\begin{tabular}{|c|c|c|}
\hline No. & Aspek yang diamati & Skor \\
\hline 1. & Pra pembelajaran & 3,5 \\
\hline 2. & Membuka Pembelajaran & 2,5 \\
\hline 3. & Kegiatan Inti Pembelajaran & 2,55 \\
\hline 4. & Penutup & 3 \\
\hline & Skor Total & 11,55 \\
\hline & Skor Rata-rata & 2,88 \\
\hline
\end{tabular}
Observasi Awal 
Dari hasil observasi tersebut, diperoleh data hasil pelaksanaan pembelajaran dalam menulis karangan narasi sebelum menggunakan metode peta pikiran (mind mapping) pada pembelajaran bahasa Indonesia dengan skor rata- rata 2,88. Skor ini dikategorikan cukup.

\section{Tabel 2}

Hasil Kemampuan Menulis Karangan Narasi Siswa Kelas V SDN 34 Palopo Kota (Observasi Awal)

\begin{tabular}{|c|c|c|c|}
\hline No. & Indikator & $\begin{array}{c}\text { Skor total } \\
\text { seluruh siswa }\end{array}$ & Persentase \\
\hline 1. & $\begin{array}{l}\text { Kesesuaian judul dengan isi } \\
\text { karangan }\end{array}$ & 900 & $81,08 \%$ \\
\hline 2. & Isi karangan / gagasan & 850 & $76,57 \%$ \\
\hline 3. & Organisasi isi & 820 & $73,87 \%$ \\
\hline 4. & Ketepatan pilihan kata & 460 & $41,44 \%$ \\
\hline 5. & Ejaan dan tanda baca & 400 & $36,03 \%$ \\
\hline
\end{tabular}

Tabel 3

\section{Hasil Belajar Siswa}

\begin{tabular}{ccc}
\hline No. & Skor & Frekuensi \\
\hline 1. & $0-9$ & - \\
\hline 2. & $10-19$ & - \\
\hline 3. & $20-29$ & - \\
\hline 4. & $30-39$ & 2 \\
\hline 5. & $40-49$ & 7 \\
\hline 6. & $50-59$ & 3 \\
\hline 7. & $60-69$ & 15 \\
\hline 8. & $70-79$ & 6 \\
\hline 9. & $80-89$ & 3 \\
\hline 10. & $90-99$ & 1 \\
\hline 11. & 100 & - \\
\hline & Total & 37 \\
\hline & Rata-rata kelas & 61,80 \\
\hline
\end{tabular}

Nilai rata-rata dari hasil belajar siswa dalam menulis karangan narasi yaitu 61,80. Sesuai dengan KKM (Kriteria Ketuntasan Minimal) mata pelajaran bahasa Indonesia adalah 70, maka siswa yang telah mencapai KKM berjumlah 10 siswa, dengan kata lain $27,02 \%$.

\section{Paparan Data Siklus I}

\section{Tahap Perencanaan}

Pada tahap perencanaan ini tindakan siklus I dilaksanakan selama 2 kali sertemuan ( 4 × 35 menit). Pada tanggal 25 September 2012, peneliti bekerja sama 
Siswa ditugaskan untuk menulis sebuah karangan dari peta pikiran yang mereka buat. Pada proses ini, guru kurang memberikan bimbingan. Guru hanya berkeliling dan membantu siswa jika siswa bertanya tentang kesulitan mereka saat menulis karangan. Tetapi terlihat bahwa yang mau bertanya hanya beberapa saja. Sehingga guru pun hanya sesekali saja memperhatikan siswa menulis karangan. Selanjutnya adalah proses penyuntingan karangan. Dimana proses ini adalah tahap terakhir dalam menulis yang menentukan penyempurnaan karangan narasi siswa. Guru menjelaskan langkah-langkah dalam proses penyuntingan yang harus dilakukan siswa. Langkah-langkah tersebut adalah (a) membaca keseluruhan karangan, (b) menandai hal-hal yang perlu diperbaiki, dihilangkan maupun yang perlu disempurnakan, (c) melakukan perbaikan sesuai dengan temuan saat penyuntingan. Tetapi dalam proses ini guru kurang membimbing siswa, sehingga siswa tidak terlalu mengerti yang harus dilakukannya. Siswa hanya membaca karangan mereka dan menganggap karangan mereka sudah baik. Sehingga bagi mereka adalah yang penting karangan mereka selesai.

Selanjutnya guru menugaskan siswa untuk mengumpulkan hasil karangan mereka beserta peta pikiran yang mereka buat. Kegiatan berikutnya siswa bersama guru membuat kesimpulan dan refleksi proses pembelajaran. Kegiatan pada pertemuan kedua diakhiri dengan membaca doa dan salam penutup.

\section{Tahap Observasi Siklus I}

Berdasarkan observasi yang telah dilakukan saat perencanaan sampai dengan pelaksanaan dan hasil menulis karangan narasi siswa pada siklus II sebagai berikut.

\section{Tabel 4}

\section{Penilaian Pelaksanaan Pembelajaran terhadap Guru} Siklus I

\begin{tabular}{|c|c|c|}
\hline No. & Aspek yang diamati & Skor \\
\hline 1. & Pra pembelajaran & 3,5 \\
\hline 2. & Membuka Pembelajaran & 3,75 \\
\hline 3. & Kegiatan Inti Pembelajaran & 3,03 \\
\hline 4. & Penutup & 3 \\
\hline & Skor Total & 13,28 \\
\hline & Skor Rata-rata & 3,32 \\
\hline
\end{tabular}

Dari hasil observasi tersebut, dapat dilihat telah terjadi peningkatan dalam pelaksanaan pembelajaran dengan menggunakan metode peta pikiran pada pembelajaran bahasa Indonesia dengan skor 3,32. Skor ini dikategorikan baik. Selisih peningkatan dari observasi awal adalah 0,44 .

Selanjutnya hasil observasi kemampuan menulis karangan narasi dengan menggunakan metode peta pikiran (mind mapping) pada siklus I. 
peningkatan skor menjadi 13,28 dengan rata-rata 3,32 dan pada siklus II mengalami peningkatan lagi dengan skor 14,97 dengan rata-rata 3,74. Dari hasil tersebut dapat disimpulkan bahwa pembelajaran kemampuan menulis narasi dengan metode peta pikiran (mind mapping) dapat dilaksanakan guru sebaik mungkin.

Tabel 11

Rekapitulasi hasil Penilaian Menulis Karangan Narasi

\begin{tabular}{|c|c|c|c|c|}
\hline \multirow{2}{*}{ No. } & \multirow{2}{*}{ Indikator } & \multirow{2}{*}{ Base Line } & \multicolumn{2}{|c|}{ Capaian di } \\
\hline & & & Siklus I & Siklus II \\
\hline 1. & $\begin{array}{l}\text { Kesesuaian judul dengan isi } \\
\text { karangan }\end{array}$ & $81,08 \%$ & $83,78 \%$ & $81,08 \%$ \\
\hline 2. & Isi karangan / gagasan & $76,57 \%$ & $87,38 \%$ & $94,59 \%$ \\
\hline 3. & Organisasi isi & $73,87 \%$ & $89,18 \%$ & $92,79 \%$ \\
\hline 4. & Ketepatan pilihan kata & $41,44 \%$ & $58,55 \%$ & $71,17 \%$ \\
\hline 5. & Penggunaan ejaan dan tanda baca & $36,03 \%$ & $46,85 \%$ & $66,67 \%$ \\
\hline
\end{tabular}

Dapat dilihat dari tabel tersebut, pesentase kemampuan siswa menulis karangan narasi berdasarkan setiap indikator kinerja mengalami peningkatan. Jadi secara umum metode peta pikiran (mind mapping) yang digunakan dalam proses pembelajaran bahasa Indonesia berhasil meningkatkan kemampuan siswa menulis karangan narasi siswa kelas V SDN 34 Palopo Kota. Dengan demikian metode peta pikiran (mind mapping) baik diterapkan pada saat proses pembelajaran bahasa Indonesia untuk meningkatkan kemampuan menulis siswa.

\section{SIMPULAN DAN SARAN Simpulan}

Berdasarkan uraian yang telah dipaparkan, maka dapat ditarik simpulan hal-hal sebagai berikut (1) pelaksanaan pembelajaran yang dilakukan oleh guru dengan menggunakan metode peta pikiran (mind mapping) pada materi menulis karangan narasi, telah terlaksana dengan baik dan terjadi peningkatan. Hal tersebut juga berdampak pada hasil belajar siswa yang meningkat, (2) penggunaan metode peta pikiran (mind mapping) dapat meningkatkan kemampuan siswa dalam menulis karangan narasi baik dari aspek kesesuaian judul dengan isi karangan, isi karangan/gagasan, organisasi isi, ketepatan pilihan kata, ejaan dan tanda baca. Hal ini dapat dilihat dari hasil menulis karangan dari siklus I sampai siklus II. Pada siklus I dengan rata-rata kelas 73,15 atau sekitar 70,27\% siswa telah mencapai ketuntasan. Kemudian padasiklus II mengalami peningkatan 8,11 menjadi 81,26 atau sekitar 91,89\% siswa mencapai ketuntasan.

\section{Saran}

Hasil penelitian tindakan yang telah dilakukan dalam proses pembelajaran menulis karangan narasi dengan metode peta pikiran, ternyata dapat meningkatkan hasil belajar siswa. Oleh karena itu dapat disarankan yaitu (1) guru bahasa Indonesia hendaknya dapat menerapkan metode peta pikiran (mind 


\section{DAFTAR RUJUKAN}

Anas Sudijono. (2010). Pengantar Statistika Pendidikan. (cetakan ke-22). Jakarta: PT Raja Grafindo Persada

BSNP. (2006). Kurikulum Tingkat Satuan Pendidikan SD/MI. Jakarta: Depdiknas

Burhan Nurgyantoro, dkk. (2009). Statistik Terapan Untuk Penelitian IImuIImu sosial. Yogyakarta: Gadjah Mada University Press

Burhan Nurgyantoro. (2010). Penilaian Pembelajaran Bahasa Berbasis Kompetensi. (cetakanke-1). Yogyakarta: BPFE-Yogyakarta

Gorys Keraf. (2004). Argumentasi dan Narasi. (cetakan ke-15). Jakarta: Gramedia Pustaka Utama

Hadari Nawawi. (2007). Metode Penelitian Bidang Sosial. (cetakan ke-12). Yogyakarta: Gadjah Mada University Press

Iskandar. (2011). Penelitian Tindakan Kelas. (cetakan ke-3). Jakarta: Gaung Persada

Khundaru Saddhono dan St. Y. Slamet. (2012). Meningkatkan Keterampilan Berbahasa Indonesia. (cetakan ke-1). Bandung: Karya Putra Darwati

Kunandar. (2011). Langkah Mudah Penelitian Tindakan kelas Sebagai Pengembangan Profesi Guru. (cetakan ke-7). Jakarta: Rajawali Pers

Lamuddin Finoza. (2009). Komposisi Bahasa Indonesia. (cetakan ke-16). Jakarta: Diksi Insan Mulia

Main Sufanti. (2010). Strategi Pengajaran Bahasa dan Sastra Indonesia. (cetakak ke-1). Surakarta: Yuma Pustaka

Melvin L. Silberman. (2011). Active Learning: 101 Cara Belajar Siswa Aktif. (cetakan ke-4). Bandung: Nusamedia

Nabisi Lapono, dkk. (2008). Belajar dan Pembelajaran SD. Jakarta: Direktorat Jendral Pendidikan Tinggi Departemen Pendidikan Nasional

Puji Santosa, dkk. (2009). Materi dan Pembelajaran Bahasa Indonesia SD (cetakan ke-11). Jakarta: Universitas Terbuka

Suparno dan Mohamad Yunus. (2008). Keterampilan Dasar Menulis. (cetakan ke-18). Jakarta: Universitas Terbuka

Suyatno. (2009). Menjelajah Pembelajaran Inovatif. (cetakan ke-1). Surabava: Masmedia Buana Pustaka

Tony Buzan. (2010). Buku Pintar Mind Map Untuk Anak. Jakarta: Gramedia Pustaka Utama

Wijaya Kusumah dan Dedi Dwitagama. (2011). Mengenal Penelitian Tindakan Kelas. (cetakan ke-4). Jakarta Barat: PT Indeks 